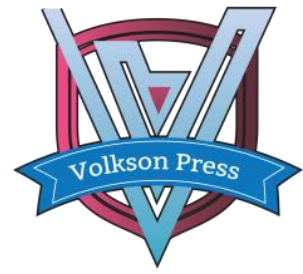

Contents List available at VOLKSON PRESS

Economics \& Management Innovations(EMI)

DOI : http://doi.org/10.26480/icemi.01.2017.157.158

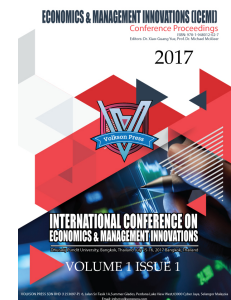

\title{
Investigating the cultural transferring to design in the trainers industry
}

\author{
Hui-Juan Zhang ${ }^{1 *}$, YuYang ${ }^{2}$ \\ ${ }^{1}$ Art Design at China-ASEAN International College, Dhurakij Pundit University, Thailand \\ ${ }^{2}$ Art Design at China-ASEAN International College, Dhurakij Pundit University, Thailand \\ *zhang.hui@dpu.ac.th
}

This is an open access article distributed under the Creative Commons Attribution License, which permits unrestricted use, distribution, and reproduction in any medium, provided the original work is properly cited.

\section{ARTICLE DETAILS}

\section{Article History:}

Received 02 october 2017 Accepted 06 october 2017 Available online 11 october 2017

\section{Keywords:}

cultural transfer, trainers,

marketing, design...

\section{ABSTRACT}

This paper is dedicated to the managers, designers and researchers involved in exploring the complexities between marketing, culture and design, especially to those who are employing in the trainers industry. Through my case studies, cultural transferring to design in the trainers industry is feasible for marketing strategies, and provides an upgrading strategy to help trainers enterprises to transform their market positioning and operating modes to obtain better development opportunities.

\section{Introduction}

The emergence of fast digital barrier-free communications and social media not only changes the design approach, but the conceptual model of cooperative design(Hall, 2013). This situation significantly happens in the trainers designing. Trainers have become a cultural symbol of all kinds of fashion elements as well as global social change. Culture as a resource has been gained by trainer designers to promote culture-orientated product innovation. My research will be closely related to these areas: social media, fashion, brand, collaborative imagination and productivity.

\section{Research background}

The cultural creativity has been enhanced significantly and fundamentally in a global context. Before the advent of digital technologies, we interacted with other cultures through slowly processes, such as exchanging artifacts, giving to exhibiting or trading. It is an obvious fact that different cultures have deep and close contacts with each other in a more complex and diversified age. As the specific product of the cultural times, trainers could help researchers to explore how collaborations take advantage of cultural differences for exchanging knowledge to make new things.

For trainers, I shall argue, they have cultural significance in terms of class, gender, and ideology. More specifically, trainers culture, according to sociologist (Kawamura, 2016), with its metaphorical meaning, it is able to present individual's habits, lifestyles, and even ideological position. When luxuries brands, such as LV, Christian Louboutin, and Valentino starts to produce trainers, trainers have developed far beyond the function of 'sport shoes'. These trainers represent a personal cultural appeal. The person who wears trainers are not simply being a sports enthusiast, instead are being a spokesman of culture or fashionmonger.

\section{Traditional trainers marketing and design approach}

Henry Nelson McKinney, who worked for advertising agency N.W. Ayer \& Son, used the word "sneaker" to describe the character that the rubber sole made the shoe stealthy. Converse Chuck Taylor All Star is regarded as the birth of term "Sneaker", and the Original Converse All Star, which was released in 1917 is one pair of most successful trainers (Beazley, 2015). The history of trainers is less than one hundred years. However, the way that trainers designed has been a dramatic shift.

In the early stage, trainers designers mainly focused on the functions and technologies. Converse Chuck Taylor All Star was designed to give basketball players more comfort and coolness. Vans Authentic was designed as a deck shoe without any notion to become a cultural symbol especially for skateboarding. New Balance 574 originally designed for ruining. These designs started with sketches, then a scale model and prototype, then full-size in the final materials. It developed with a linear creative process. Interactions primarily happened between designers and manufacturers.

\section{New trainers marketing and design approach}

The Air Jordan III was an innovative basketball shoe design. Designer Tinker Hatfield invited basketball player Michael Jordan together to design the shoes. Culture transfer took place in a creative collaboration with different aesthetic tastes.

The trainers Collaboration seems to become more ubiquitous because various new collaboration trainers are released weekly for consumers to freely choose. The collaboration design seems to be the trend of future trainers design because it almost could not be influenced by inherent design. Material, style, function or represent culture can be created according to the requirements of consumers. At present, a large number of collaborators such as artists, musicians, shop owners, and magazine editors design trainers together with some sport companies.

The digital mediums that were being used began to change the way that designs evolved. They freed decision making from the slow exchange of paper and models towards a fluid exchange of material on computer files(Hall, 2013).

Grammy awarding-winning hip-hop artist Kanye West joined the Adidas as a professional designer. He usually shares his design inspiration through social media to influence customers. The interaction between designers and customers has shifted to a global network. The digital mediums have changed the way of design, and blurred the boundaries between designers and customers. Nike and Adidas have provided the services that anyone can design their own sneaker on the website. Hall (2013) concludes that culturally driven design can provide great sentimental value. Hickling-Hudson et al. (2007) makes the point that this area of knowledge which can support designers to purposefully blend user's culture into designing products is underdeveloped.

"Design is all around us. It seems inevitable, then, that design will reflect or perhaps even help to define the popular culture of the era and society in which we live. Indeed, mass produced design might be seen as a central pillar 
of popular culture."(Jordan, 1998).

\section{Experiential trainers design in Chinese marketing}

My research aims to promote culture-orientated product innovation. I believe it is not only benefit for trainers design, but other cultural transfer designs under the new social structures. Actually, I have interacted with Chinese trainers and fashion Manufacturers, such as Hangzhou Leizu Co., Ltd, to understand cultural flow and designed one pair of trainers for them. The Manufacturer of Hangzhou Leizu Co., Ltd accepted this and design and plan to produce this trainers in 2017 summer.

The case

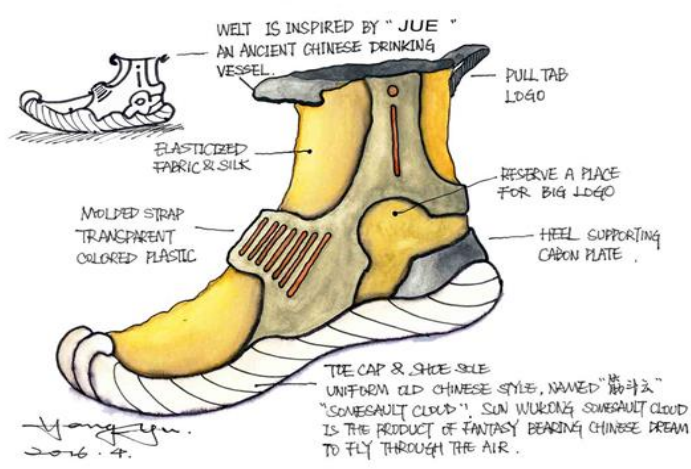

Draw by Yang Yu, 2016

In general, this series of trainers present new free life style, showing vitality anywhere anytime. They own uniform toe cap and shoe sole. The sources of inspiration come from "Somersault Cloud" and the traditional lifting Chinese toe cap. The traditional lifting Chinese toe cap designed before more than one thousand years ago in China.

\section{Conclusion}

Along with the global economic integration, the trainers' market competition is more and more intense. Most trainers enterprises are inevitable to join the international competition. Due to their hardware has gradually become homogeneous. The competition between the trainers business competition has upgraded from the producing and design capacity to cultural communication ability.

This paper explores the influence of culture on the design of trainers, and analyzes the Adidas and Nike trainers design. Through my own design practice, I would like to give some inspiration. In the use of traditional culture, trainers enterprises need to seek the spirit of the design coincide with the movement, and modern fashion combination, and gradually formed a unique trainers culture.

\section{References}

[1] Hall, A. 2013. Translocated making in collaborative experimental design projects. $\mathrm{PhD}$ thesis, University of Technology Sydney.

[2] Hickling-Hudson, A., Popovic, V., \& Moalosi, R. 2007. Product analysis based on Botswana's postcolonial socio-cultural perspective.

[3] Jordan, P. W. 1998. Popular culture and design. Global Ergonomics: 467.

[4] Kawamura, Y. 2016. Sneakers: Fashion, Gender, and Subculture: Bloomsbury Publishing.

[5] Beazley, M. (2015). Icons of Style: Sneakers. London: Octopus, 9- 